\title{
Prophetic gestures: how Blake drew his Virgil
}

\author{
Joan Curbet \\ Universitat Autònoma de Barcelona \\ joan.curbet@uab.cat \\ https://orcid.org/0000-0002-3540-2101
}

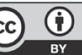

\section{Riassunto}

Questo articolo si concentra su una figura specifica dell'adattamento visivo della Commedia di Blake: Virgilio, che Dante ha invocato sia come predecessore poetico che come modello etico. I gesti e gli atteggiamenti fisici del personaggio nelle tavole di Blake suggeriscono un inserimento di questa versione di Virgilio all'interno della tradizione della scrittura sacra che l'autore considerava profetica. Come vedremo, ciò ha comportato una decisione consapevole da parte di Blake di abbandonare i valori fondamentali e il significato più ampio di Virgilio nella Commedia originale. L'articolo cerca di offrire una lettura della versione di Blake del poeta mantovano basata sulle nozioni di profezia che egli aveva sviluppato tra il I804 e il I820, nelle sue illustrazioni per le opere di John Milton e nel poema miniato Gerusalemme, che deve essere considerato la sua ultima e più decisiva affermazione sull'argomento. Ciò che emergerà non sarà una prospettiva definitiva sul Virgilio di Blake (nessuna lettura può essere considerata "definitiva" per quanto riguarda Blake), ma una in cui i gesti profetici della figura appariranno in tutta la loro potenzialità di significato.

Parole chiave: Blake; Dante; Virgilio; profezia; gesti; porte dell'Inferno.

\begin{abstract}
This article concentrates on one specific figure in Blake's visual adaptation of the Commedia: Virgil, whom Dante invoked both as a poetic predecessor and as an ethical model. The gestures and physical attitudes of the character in Blake's plates suggest an insertion of this version of Virgil within the tradition of sacred writing that the author considered as prophetic. As we shall see, this involved a conscious decision on the part of Blake to abandon the core values and the larger significance of Virgil in the original Commedia. The article attempts to offer a reading of Blake's version of the Mantuan poet based on the notions of prophecy that he had developed between 1804 and I820, in his illustrations for the works of John Milton and in the illuminated poem Jerusalem, which must be considered his final and most decisive statement on the subject. What will emerge will be not a definitive perspective on the Blakean Virgil (no readings can be considered "definitive" in what concerns Blake), but one in which the prophetic gestures of the figure will appear in all their potentiality of meaning.
\end{abstract}

Key Words: Blake; Dante; Virgil; prophecy; gestures; gates of Hell. 
To a large extent, we are still catching up to William Blake's reading of 1 Dante. The twenty-first century has seen several attempts to describe and/or interpret the nature of the relationship between the two poets, but (among more strictly literary concerns) a detailed iconological study of Blake's plates on the Commedia is still missing. A possible reason for this is our failure to recover the prophetic nature of the visual experience that Blake attempted to convey. We have become so accustomed to de-theologized critical work on both authors (to use the term coined by Teodolinda Barolini three decades ago) that we have gone to the other extreme, and reified the political and the historical, often at the cost of other nuances. And yet, for William Blake the prophetic element did not necessarily lead into theology: it was a release of human capacities that allowed for a renewed ability for perception, understood in immanent terms.

The connection between Blake's illustrations to the Commedia and his previous illuminated works has of course been explored before; however, it has also been questioned. The twenty-first century has been more skeptical as to the nature of these links, thanks to a great extent to the work of David Fuller and of Antonella Braida. The first claimed that "modern Blake scholarship has taken these illustrations to be highly and continuously interpretative. They are, in my view, much more literal than the modern reading allows."(Fuller 1988: 349). It is only logical, within the development of critical discourse, to formulate notably different approaches to works that have generated controversy from their very beginnings. Antonella Braida has offered the most skeptical approach to the analyisis of the illustrations in terms of Blake's previous works:

Although useful, this approach (...) has left a difficult inheritance in the analysis of the plates: it has involved viewers and critics in a dangerous process of participation in which suspicious insertions in the plates are interpreted on the basis of a plethora of references to Blake's poems. Where does this associative process end? Are then the plates, by means of their late completion, to be considered a summa of Blake's poetic production? (Braida 2003:9I)

The answer to this question must of course be negative. But that does not sever the existing links between the plates and (at the very least) Blake's prophetic works of the I89os and 20s. As long as the links between them and the Commedia plates are solidly justified and coherently described, there is no serious reason to discard them: a misguided literalism would be here as crippling and reductive as a simplified list of fixed, static correspondences. ${ }^{\mathrm{I}}$ In

I. Even though prominent scholars such as D. Fuller (1988) or A. Braida (2003) have distanced themselves strongly from the concept of "prophecy" in relation to Blake's version of the Commedia, the present article argues in favour of a critical recovery of it. 
the present article, I will proceed according to the lucid perspective established by W.J.T. Mitchell, and which attests to the continuity between Blake's illuminated works and the milestones that the poet regarded as his predecessors:

(Blake) knew Paradise Lost and even the Bible by heart. This is not only a matter of numerous echoes, allusions and parallels, but a function of the ontological status of the illuminated books. One suspects the Blake saw them, as the Divine Comedy and Milton's poems, as the extension of the one only holy book whose writing has been in progress since the beginnings of sacred literature. (Mitchell 1978:I22)

The next pages will offer an exploration of Blake's insertion of Virgil within that tradition of sacred writing. As we shall see, this involved a conscious decision on the part of Blake towards abandoning completely the core values and the larger significance of Virgil in the original Commedia. If this was a misreading of the character, then it was surely one in the Bloomian sense of the term: a wilful move against the original, in which the poet/artist strives to impose his own reading over that which has been handed down to him in the text of his predecessor. ${ }^{2}$ However, I do not intend to offer a Bloomian interpretation in the present article: this would involve a narrowing down of the possibilities implied by Blake's definition of the prophetic role. Instead, what I intend to offer is an interpretation of Blake's version of the Mantuan poet based on the notions of prophecy that he had developed between 1804 and 1820 , in his illustrations for the works of John Milton and in his illuminated poem Jerusalem, which must be considered his final and most decisive statement on the subject. What will emerge will be not a definitive perspective on the Blakean Virgil (no readings can be considered "definitive" in what concerns Blake), but one in which, at least, the prophetic gestures of the figure will appear in all their potentiality of meaning.

It is well known that the scenography of Blake's Commedia does not rely on a simple reproduction of the contents offered by each of the Dantean cantos. His visual rendering is entirely anti-academic: the space that is devoted by the artist to the various scenes of the poem may vary according to the signifiying force he attributes to each of them, without regard to their length in the original text. By extending or contracting the length of the original episodes, Blake compels the viewer to do the same and to consider the value of every separate plate in itself. This is also one of the reasons why Virgil's prophetic status is not represented systematically but by accumulation, through a series of gestures that may vary through the whole series, but which attest to an ultimate conceptual coherence. The artist's aim is to unlock the prophetic potential of the viewer, in a way that replicates Virgil's unlocking of such potential in

2. This concept is developed at length by Harold Bloom in his influential A Map of Misreading (Bloom 1975). 
Dante. The iconographic gestures of the character are thus deployed through a strategic repertoire, always endowed with purposeful connotations, as I hope to show in the following pages.

\section{BEYOND ROMANITAS}

At one point in his now classic study Dante and the Idea of Rome, Charles M. Davis briefly and memorably defines the Dantean idea of Virgil as "a bridge between the two Romes": the historical empire of the past and the Christian empire of the future, an idealized "Roma onde Cristo è romano" (Pg.XXXII, I02) (Davis 1957: 137). Giuseppe Mazzotta has also argued convincingly that the Dantean attitude towards Virgil is one which encompasses not only poetic influence, but a strong set of values that the later poet desires to integrate (not unproblematically nor without tensions) in his own vision of the translatio imperii.

Dante reads the Aeneid as a poem of love, the generalized desire that shapes the world of history and is the root of history. Dante (...) is deeply interested like Virgil in the outward history of Rome and, like Virgil, he wants to penetrate it, to grasp the ethical core of the values of Romanitas, of the voluntarism that supports these values (Mazzotta, 1980: 150) ${ }^{3}$

In terms of the absorption of cultural history, this is precisely the point at which Blake had to diverge from Dante. For the English poet, and at least since the late I890s, romanitas could not be separated or meaningfully distinguished from Greek culture: the whole of classical culture was a legacy that he could not ignore, but which he saw as deeply opposed to the Hebraic and Christian traditions fostered by the Bible. The handwritten text that surmounts his first sketch for Canto II of the Inferno, in which Homer stands out starkly at the center upholding a sword in his hand, includes the passionate assertion (with the customary lack of punctuation): "Homer is the Center of All I mean the poetry of the Heathen Stolen and Perverted from the Bible not by Chance but by design by the kings of Persia and their Generals the Greek heroes and lastly by the Romans"(quoted in de Santis 2017: 73-74). No sense of translatio imperii can bring about any serious recovery of classical values, since these were perverted from the beginning: the classical epic, despite its suggestive power, had implied a glorification of war and conquest which Blake opposed through all his career. As a result, the Dantean image of Virgil had to be not only relativized, but cancelled. Since Blake's approach was visual, there was no place even for a verbal sense of influence here, despite the fact

3. In the second part of his chapter on this matter, Mazzotta goes on to identify the deeper ambiguities that lie behind such a poetic and ideological project: for, after all, "if Virgil is the poet of history, this means that history cannot be taken literally" (Mazzotta 1980: 158). 
that Dante had called the Mantuan poet "lo mio maestro e'l mio autore" (If. I, 85 ), defining him both as a literary model and as an image of ethical auctoritas. This model had to be replaced, and this is what occurs, in terms that must have appeared as radical to the potential public of Blake's work, in his plate for Canto I (figure I).

First of all, it is necessary to insist on the fact that Blake often uses some of the more specific or local metaphors of the Commedia in order to integrate them into the larger scenery of his illustrations. Thus, the sea does not appear in the scenery of the "selva selvaggia" in Dante's first Canto, but Blake represents it to the left of his plate for Canto I; quite obviously, he is enlarging one of the metaphors that Dante uses in order to explain his moral transition from confusion to hope, in lines 22 to 27 ("E come quel che con lenna affanata/ Uscito fuor del pelago a la riva...", etc). It is important to point this out as an example of the general tendency followed by Blake throughout his adaptation: all of the material used by Dante can become part of the illustrations, often independently of its status in the original text (as an illustrative or momentary comparison, for instance). ${ }^{4}$ The sea that opposes the forest turns in Blake into an essential part of his plate on Canto I, in order to underscore the promise of freedom for Dante the pilgrim, and also in order to point out the essential difference in the two human figures appearing in the plate: one running over the ground and with feet firmly and painfully set on it, the other hovering over a watery, moveable and fluid landscape. The naked and thorny earth is an adequate ground for a misguided pilgrim, but water and air are the adequate surroundings for a bearer of spiritual illumination. It is also an adequate difference between one character (Dante) who is uncertainly striving towards moral clarity and one (Virgil) who has reached full moral and prophetic capacity.

What is achieved in this first presentation of Virgil? An initial and necessary step: the complete transformation of the character from Dantean romanitas to Blake's idiosyncratic sense of enlightened Christianity. No laurel wreath is necessary here, no indication of poetic auctoritas: achieving spiritual wisdom is not simply to overcome the natural world, but to understand it in a way that is not binding to its laws. Hovering male bodies, apparently free from the constraints of gravity and serenely static, had been abundantly depicted by Blake in the twenty years preceding his work on Dante. One of his major approaches to this trope is to be found in his illustrations to Milton's Paradise Regained (elaborated around 1816), in the scenes corresponding to the third temptation of Christ. In the culminating scene of that series (figure 2), Blake depicts the body of Christ impossibly standing on a single toe on top of the

4. Silvia de Santis has made the same point, but without going in depth into its implications in what concerns the role of prophecy in the sequence of illustrations (de Santis 2017: 126-27). 
highest spire of the temple of Jerusalem, while Satan falls towards the ground before him, grotesquely coiled. Here Blake goes as far as he can to emphasize the uncanny sense of levitation in the human figure, an aspect that is not present in Milton's text, and that is completely alien to the episode as presented in the evangelical sources (Matthew 4:I-II and Luke 4: I-I3). Without pressing the parallelism too far, I would like to point to the essential similarity between that particular rendering of Christ and Virgil's appearance in the first plate for the Commedia. If Virgil appears there as an angelic character, or even as Christ-like himself (in the Blakean sense, which emphasizes the glory and freedom of the character over his sacrificial role), this is only a consequence of the strong re-reading that Blake intends: one that divests the Mantuan poet of his magisterial status as a Roman classic and invests him with a new, albeit idiosyncratic, form of spiritual enlightenment; and such an enlightenment takes him beyond the laws of nature itself. Gravity, after all, is one of the most visible forms of the "Newtonian laws" against which Blake had passionately positioned himself.'

It must not be forgotten that one of the main attributes of Christ was, both for Blake and for Milton, his role as a prophet, announcing the end of the Mosaic Law and its substitution by a new covenant. Blake's Virgil quite naturally inherits this latter characteristic (after all, and as Blake well knew, he was credited with having announced the birth of Christ in his Ecloga IV). But, as I have stated at the beginning, this prophetic condition is not communicated to the reader by one single unambiguous image, but rather by a strategic accumulation of gestures in the first plates. It is to these gestures that we must now turn.

It would perhaps be tempting at this point to begin a detailed identification of the two characters, Virgil and Dante as they appear in the first plate, with the mythical Blakean archetypes of Los and Albion (the former bringing enlightenment, prophetic spirit and freedom; the latter undergoing several processes of change until the liberation of all his inner strength). I shall in fact use some aspects of this potential identification in the rest of this article. But I would like to stress at this moment that such an identification is not indispensable for our interpretation of the plates, nor would Blake have wanted it to be. It will be useful for us to take into account the similarities between the two sets of characters, however, in order to establish a sense of continuity between Blake's work of the I8Ios and 20 (especially in what concerns prophecy) and his illustrations for the Commedia.

5. For an account of Blake's early responses to the figure of Newton and Hume, and his mistrust of the claims of science as the language of objective truth, see Jon Mee 1992: 138-44. 


\section{FIRM FEET AND SURE HANDS}

The beginning of Dante's journey is marked by a strong sense of tiredness which is of moral origin, but which seems to communicate itself to the body, or to be signified by it: "Poi ch'ei posato un poco il corpo lasso,/ ripresi via per la piaggia diserta,/ si che'l piè fermo sempre era'l più basso." (If. I, 28-30). John Freccero has made it clear, in a deeply suggestive essay on these lines, that the firm foot ("piè fermo") is to be identified, following St. Bonaventure's sermons (specifically, Domenica Tertia in Quadragesima), with the right foot, the one that takes the first step in the movement away from sin:

One foot is the movement of reason, the other the movement of appetite. The first one is on the right, the second on the left, since the right foot is moved first, and the left afterward...The first foot is the awareness of sin, the second, that of the left foot, is desire, the third, of the right foot, deliberation, and the fourth, of the left foot, choice. (Quoted in Freccero, 1986: 42)

We could add to those implications several more in a similar direction, coming from Platonic and Neoplatonic traditions of interpretation of the bodily forms, as Freccero does in the latter part of his magisterial essay. In any case, most of these contents are absorbed and preserved in Blake's rendition of the first Canto of the Commedia, in a simple and straightforward manner which has been duly noticed by scholars. A.S. Roe, for instance, has identified the respective positions of Dante's and Virgil's feet in the first plate as opposed, with the right foot corresponding to spirituality, and the left foot to materiality (Roe 1953:49). Roe was following a path that had already been marked out by Joseph H. Wicksteed in his discussion of Blake's Book of Job (Wicksteed I9Io). What matters to us now, however, is how this movement is combined with others in this specific plate and in the following ones, in order to complete a sense of Virgil's role that goes far beyond that of a protective figure.

To begin with, let us remember that Christ himself, the supreme prophet according to Blake, had already been depicted by him only a few years before as standing firmly on a finger of his right foot on the highest spire of Jerusalem (figure 2). The choice of that specific gesture there was very deliberate, since there was no basis for it in Blake's original sources, either Miltonic or Biblical: there Christ's resistance was simply verbal (in the gospels) or limited to the fact of standing and not falling (in Milton). The position of the feet in that former image is not only repeated by the character of Virgil in plate I, but also in plate IV, when entering the gates of Hell: there the gesture is not made to come to the encounter of Dante, but to lead the way for him and penetrate boldly into the depths of the earth (figure 3). In both illustrations (plates I and IV, figures I and 3), the position of Dante's feet is exactly the reverse of Virgil's. It becomes clear, then, that the two poets are in different positions not 
only in relation to their moral position (plate I), but also in relation to their capacity for vision. In the later image (plate IV), Virgil is also taking Dante by the hand, guiding him along on the way to illumination.

The gesture of taking a person by the hand in order to make them advance in physical and spiritual terms had been a recurrent one for Blake, in the years leading to his work on the Commedia. One example that stands out particularly in this context, and which usefully coincides and contrasts with the plate for If. III, is his plate representing the archangel Raphael taking Adam and Eve by the hand out of the Garden of Eden: an illustration for the final page of John Milton's Paradise Lost (figure 4). A superior spiritual authority is here, as well, leading the characters on their track towards a transformation of the self. The gesture is also one of guidance, and we have to remember that Raphael specifically acts as a prophet in Paradise Lost, announcing the whole development of human history. Here we have, then (figures 3 and 4 ), an excellent parallel between Blake's visual adaptations of Milton and of Dante, one taken from the beginning and the other from the end of each epic, and both showcasing an initiation along the road to spiritual progress, and thus towards a difficult but certain plenitude.

The only objection that could be made to this pairing could come, precisely, from the position of the feet in the plate for Blake's version of Paradise Lost: here Eve and Adam advance with their right feet onwards, while Raphael does so with his left. But does this really contradict the respective status of the spiritual authority in relation to those that he guides in the two pictures (Dante in one case, Adam and Eve on the other)? Not if we take into account the specific situational pattern of Paradise Lost XII, in the lines rendered into images by Blake. Raphael is not about to guide Adam and Eve once they have come outside of the garden: he is going to remain there and let them to make their way on their own; he will stay in the province of spiritual plenitude, while they start their long and difficult journey towards recovering it. As for the two human characters, they have already started on the road that they have taken through their own free will (in both Milton's and Blake's interpretation of original sin), and hence they must necessarily be seen as advancing onwards, even if they are uncertain of their immediate future. ${ }^{6}$ The gesture of the guiding/prophetic figure is the same in both pictures, but in the first case that figure (Raphael) is going to remain behind, while we know that, in the other, Virgil will actively lead a hesitating Dante all the way up to the heights

6. For a good general treatment of Milton's approach to free will and sin, see especially Denis Danielson (1992) and Michael Lieb (2007), and for the peculiarities of Blake's own perspectives on the same subjects, see especially Thomas J. Altizer (2003). These studies must be considered, however, only as starting points of reference; the bibliography on the matter is immense. 
of Purgatory. In both cases, the figure that speaks prophetically is the one that opens the way, so that the human subject can step into it.

\section{Across THE GATE}

There is no innocent way to read the inscription over the gates of Hell in If. III: the overfamiliarity of the text has made it so commonplace that, in many ways, it is always already known by those who approach it. Blake's version of the inscription is limited to two brief, barely visible lines, penciled on top of his multi-colored illustration of the gate (figure 3, again); Dante is looking upwards and fixing his gaze on them as Virgil, taking his hand, urges him onwards. In one sense, this plate capitalizes on the universal fame of the inscription: the viewer already knows it by heart, so there is no need for the artist to reproduce it verbatim. But at the same time the image relativizes the importance of the text in order to emphasize the experience of entrance, with its implicit fear and anxiety. In the plate the brief tension between Dante and Virgil is not brought about by an understanding of the letter but of the spirit of the inscription; the precise moment of hesitation would thus correspond, I propose, with line I2 of Canto III: "Maestro, il senso lor m'è duro" (emphasis mine), which, as Blake well knew, echoes the text of John 6: 60 ("Durus est hic sermo"). Blake thus favors, at this specific moment, the global understanding of the inscription rather than the emphasis on the inscription as a text; it is the whole experiential dimension of the situation, with its tension between advance and retreat, that is projected on the viewer.

That tension, however, is already being resolved in favor of Virgil: after all, he is stepping on the gate with "piè fermo", and is projecting his right hand towards its interior. Once more here, and this time with full clarity, the role of the character is not that of a poet nor that of a moral referent, but that of a prophet who is crossing gates and opening spaces not only for himself, but for the sake of others. Here our major evidence comes from the Blake's last illuminated works: the period during which he completed and defined most strongly his notion of prophecy, and developed his art of combining poetry and engraving to its most complex degree. On the frontispiece of Blake's Milton (I804) we can see the image of the seventeenth-century poet standing with his back to the reader, facing front, stepping onwards with his right foot and extending his right hand towards what seems a formless void, which (as we learn in the development of the poem) he is going to articulate into specific forms (figure 5). This image of Milton is not blind, as the historical poet was; on the contrary, his gesture involves the capacity both for seeing and for creating, his active confrontation with a chaotic matter on which he is going to operate like a platonic demiurge. Even though Virgil is only leading Dante 
into the nether world in the plate for If. III, not preparing for any act of subsidiary or plenary creation, his attitude is also one of bold confrontation with the forces that lie before him: the similarity between both characters (Milton and Virgil) is entirely logical if we consider the fact that both of them were interpreted by Blake as figures of full visionary power.

The most compelling series of images for a full contextualization of plate IV, however, come from Jerusalem, the most enigmatic of all of Blake's works, but the one that insists most relentlessly on the significance of the prophetic mission. The frontispiece (figure 6) shows the image of a character that might be contemporary with Blake (at least in the detail of the broad-brimmed hat he is wearing), caught in the movement of entering an arched door cut on what seems to be a brick wall. As he moves into the dark that lies beyond the door, there is a sphere of light that seems to emanate from the fingers of his right hand. Crossing a gate into a gaping darkness while trying to bring illumination into it can only correspond to one of the incarnations of Los, the archetypal character embodying the spirit of prophecy in Blake, who is given his most serious mission (the awakening and resurrection of the sleeping Albion) throughout this poem. There is an obvious difference with the figure of Virgil in plate IV of the Commedia, since here it is the left hand of Los that is being projected onwards so as to open the door, but the situational pattern is analogous for both characters. Even more significant for our purposes is the image of Albion in Jerusalem, as it appears in its 97th plate (figure 7): he has awakened from his sleep of death, has acquired and mastered his own sense of revolutionary vision, and is advancing to awaken the daughters of Jerusalem from their own sleep, where they rest in passivity. Albion brings his own light, like Los did before him, but he carries it in his left hand, while the right hand is rising as if to disperse the darkness before him. He also advances steadily, stepping onwards with his right foot. Each of these predecessors of the Virgil of plate IV show some slight difference from him, but all of them, through their gestures, inscribe themselves in an archetypal category that has one final iteration in the rendering of Dante's guide: that category is none other than that of the Blakean poet-prophet.

Of course Blake knew very well that late medieval culture and neoclassicism, in their respective historical moments, had cast Virgil in the role of a prophet, but he saw their reasons (his supposed announcement of the birth of Christ) as completely irrelevant. For him, after all, the life of Christ had been above all a major spiritual event: its importance did not lie in its historicity or plausibility, or even in its transcendence. If Blake casts Virgil in a prophetic role, it is because of his own reasons: because he sees him, as he had seen his own characters Milton, Los and Albion, charged with the mission of confronting the darkness of the human spirit, of moving boldly into it and of 
illuminating it with his capacity for vision and creativity. Such a reinterpretation of the Roman poet was extremely radical for its time; in the next section we are going to see that, to a certain extent, it was also politically charged.

\section{THE PROPHETIC GESTURE}

I would like to return now to the point I made earlier, in my first section, on the possibility of establishing a connection between the Blakean version of Virgil and the figure of Christ himself. Such a connection might have seemed far-fetched at the moment, but I would like to argue now that it can be meaningful and logical within the set of thematic emphases that, as we are seeing, Blake is making in his adaptation of the Commedia.

Blake's approach to the image of Christ evolved significantly during his most creative decades (from 1790 to 1820 ). As he progressed from his first antinomian positions into the building of his very personal mythography, and from his earlier illuminated verse towards an openly prophetic interaction between poetry and image, he developed a vision of Christ as a referent and example of the humanization of God. Earlier on in his career, he had seen him as the founder of a repressive and sacrificial state religion (or a series of state religions); by the I8Ios, however, he had advanced towards the idea of non-transcendent vision of Christ as a liberator of purely human energies. By then Blake had rejected completely any idea of a God that was not immanent, and that was not incarnated in every human being. ${ }^{7}$ Once more, the essential text here is Jerusalem, in which he makes the traditional, Abrahamic God-image speak in the following terms:

I am not a God afar off, I am your brother and friend, Within your bosoms I reside, and you reside within me; Lo!; we are One; forgiving all Sins; not seeking recompense! Ye are my members. (Jerusalem, plate 4)

Such an assertion goes a long way towards the rejection of God as a transcendent creator. The term "members" here is to be understood not only metaphorically, but rather pointing towards the idea that the body of God is also, and essentially, that of the whole humanity: he is to be found "within your bosoms", not outside of them. This idea is voiced a in a number of different ways throughout the poem. At one point, it is humanity itself that pronounces it:

Why do stand we here trembling around

Calling on God for help; and not ourselves in whom God dwells

Stretching a hand to save a Falling Man? (Jerusalem, plate 38)

7. About this very important point, see W.J.T. Mitchell I973: 28I-307. 
The examples could easily be multiplied. The important fact to keep in mind is that Blake had come, in time, to assert the full humanity of God and to refuse completely the idea of a transcendent atonement carried out by Christ. His world-view could still be called "Christian", however, to the extent that he was willing to preserve the idea of Jesus as a pre-eminent prophet and king (in a purely spiritual, non-political sense), just as his main English poetic predecessor, John Milton, had done in his time. I have mentioned in the first section of this article that Blake's illustrations to Milton's Paradise Regain'd (around I8I6) can offer some interesting insights into our subject. Paradise Regain'd is perhaps the most openly heretic work that Milton ever wrote, offering a unique and radical perspective on the evangelical episode of the temptations in the desert. ${ }^{8}$ We have already seen some proximity between Blake's version of the Miltonic Christ and his own rendering of Virgil, through the visual trope of the hovering body, free from the pull of gravity and therefore free of "Newton's laws", which Blake saw as being as potentially repressive as those of organized religion. But the parallelism can be traced further. For Milton and for the later Blake, the temptations of Christ in the desert implied his achievement of a full prophetic authority, looking beyond the deceitful immediacy of the present moment (the need for food, the wish for political power, the desire to give in to idolatrous ideologies: the first, second and third temptations, respectively) and projecting the fulfilment of a truly humanistic project throughout the full development of history.

If we look now at Blake's rendering of the first and second temptations (figures 8 and 9), we can see in both cases the character of Christ standing upright in front of a peculiarly bearded Satan, who is offering him a stone in the first case (figure 8), and pointing towards the distant, three-fold structure of a city in the second (figure 9). In the first image we see Christ advancing with his right foot and giving his back to us; in the second, he is standing quietly on the edge of a precipice; in both cases, he is doubling his right arm and pointing upwards with his right hand. The gesture might well be traditional, but it certainly did not involve, for either Milton or Blake, any kind of trinitarian meaning or any vindication of the divinity of Christ. For both of them, it corresponded to his assumption of his role and authority as a prophet.

We can now turn to plate IX in Blake's Commedia (the encounter with the demonic judge Minos, figure Io) and surely enough we will be able to trace a direct continuity between this image and his own rendering of the first two temptations in Paradise Regain'd. The character of Virgil certainly shows a strong sense of tension, as befits his protective gesture towards Dante, who is crouching with fear on his left; the gesture of his right hand, however, leaves

8. For a couple of useful and short accounts on John Milton's Christology, see especially Ira Clark 1974: 104-07 and Thomas Langford 1982: 63-67. 
no doubt: he is asserting his prophetic authority exactly on the terms that Christ had done it in Blake's work for Paradise Regain'd. It is this gesture that gives him full authority before his devilish adversary, and which identifies him as a bearer of a superior spiritual truth. The representation of Minos is also significant. From among the many possible options given to him, Blake chose to emphasize one that brought the character close to the traditional features of an Abrahamic father-image, which is combined here with the unmistakably Dantean detail of the tail which he continually projects towards the souls that he is judging, and assigning to different parts of hell. We cannot ascribe to sheer coincidence his similarity to the Blakean/Miltonic Satan of Paradise Regain'd; in the Blakean world-view of his last years, both Minos and Satan (the tyrannical ruler of Crete and the fallen angel) could appear as parallel examples of ambition and material power, dramatically confronted by emancipatory, prophetic figures.

I do not postulate that Blake intended the viewer to recognize, in any way, these parallelisms between his two sets of plates (one for Milton, the other for Dante); he probably did not even expect that the eventual viewers of the first would have the chance of seeing the latter as well. What I am postulating is that the iconographic repertory of the former adaptation is fully coherent with the artistic purpose of the latter; that both resonate powerfully when understood together as expressions of the later Blake and of his dominant preoccupations, and that both of them are instances of his discourse on prophecy and its emancipatory role. The English antinomian tradition had reformulated the function of prophecy in the context of radical religious movements; John Milton had recreated it in his anti-trinitarian approach to Christ; it was left for William Blake to generate, in the near-anonymity of his later years, a visual repertory that could represent that notion expressively, and a re-definition of the character of Virgil in directions that had been unforeseen until that moment.

\section{Conclusions}

It is now possible for us to look back on our brief journey and to summarize the main conclusions of our lectures d'image. By following the Blakean itinerary of Virgil from the selva selvaggia to the first circle of hell, we have been able to establish the following aspects:

I) That the gestures of body, hands and feet in the character, both in his interaction with Dante and with his broader environment, showcase him as a prophetic figure close to the images of Los and Milton in the mythographic work of Blake during the I8Ios and I82os. It is possible to extend that perception so as to include Blake's version of Christ himself (understood as prophet) as a precedent for his Virgil. 
2) That the above-mentioned gestures take Virgil away from the values that he incarnated in Dante's poem and bring him close to the Blakean concept of the prophet as a liberator of the hidden potentialities of self and community.

3) That plate IV, representing the entrance into Hell, establishes a basic difference between "text" and "sense" that enables the illustrator to focus on the latter, and thus to reinterpret Dante's text according to his own understanding of prophecy (incidentally, such an aspect, together with the physical disposition of the characters, allows us to propose this image as corresponding specifically to line III:I2 of the original Inferno).

4) That such an act of liberation concerns not only the protagonist (Dante the pilgrim, in his own way to becoming a poet/prophet) but ultimately the viewer him/herself, on whom the act of interpretation depends.

It might be argued, of course, that we still cannot be absolutely certain that Blake preserved the major thematic concerns of Milton or Jerusalem in his adaptation of Dante in the mid-I820s. But every evidence that we have points precisely in the contrary direction: the thematic emphases that we have traced show a deepening, not an abandonment, of the iconography of prophecy as Blake had developed in his later illuminated poems. Precisely because he saw Dante's version of Virgil as a beacon for a personal transformation (the transformation of Dante as a pilgrim/character), he could re-position him as a major and powerful signifier in his own work. This was not a difficult re-appropriation as much as a fluid and logical creative step. Blake understands Dante's Virgil, away from any sense of classicism or roman civilitas, as a force of personal enlightenment and liberation not only for the protagonist of the plates, but for the viewer him/herself. The integration of the audience into the artistic performance was always a major concern for Blake.

The cultural soil of early nineteenth-century England was a particularly fertile one in what concerns the artistic appropriations of the Commedia. The artistic crossroads that were traced between what we now call "European romanticism" and the emancipatory projects that sunk their roots in national traditions gave rise to strong and politically loaded re-readings that retain much of their suggestive power today. Blake's visual adaptation remains unique, however, in understanding not only the act of creation (both Dante's original creation and his own) but also the act of interpretation, of reading and/or viewing, as being interactive and liberating. His version of Virgil responds not so much to the need of guiding the viewer along an over-familiar text, but of leading him/her to offer his/her own creative response, just as the artist himself was doing during the period of his visual adaptation of the Commedia. Death interrupted that project, but its emancipatory potential remains fully alive today. 


\section{WORKS CITED}

Altizer, Thomas J. (2003). The New Apocalypse: the Radical Christian Vision of William Blake. New York: Davies Publishers.

Barolini, T. (1992). The Undivine Comedy. Princeton: Princeton University Press.

Bloom, H. (I97I). The Visionary Company. A Reading of English Romantic Poetry. London: Cornell University Press.

Bloom, H. (1975). A Map of Misreading. Oxford: Oxford University Press.

Braida, A. (2003). The Literalism of William Blake's Illustrations to the Divine Comedy, in Image and Word, Reflections of Art and Literature from the Middle Ages to the Present, ed. By A. Braida and G. Pieri. Oxford: Legenda.

Braida, A. (2004). Dante and the Romantics. New York: Palgrave Macmillan.

Clark, I.(1974). "Christ on the Tower in Paradise Regained", Milton Quarterly 8, I04-07.

De Santis, S. (2017). Blake and Dante: A Study of William Blake's Illustrations of the Divine Comedy Including his Critical Notes. Roma: Gangemi Editore.

Danielson, D. (1992). Milton's Good God. Cambridge: Cambridge University Press.

Davis, C. (1957). Dante and the Idea of Rome. Oxford: Clarendon Press.

Fisch, H. (1999). The Biblical Presence in Shakespeare, Milton, and Blake: A Comparative Study. Oxford: Clarendon Press.

Freccero, J. (1986). Dante: the Poetics of Conversion. Cambridge, MA: Harvard University Press.

Fuller, D. (I988). Blake and Dante, in "Art History", vol.II, n.3, 349-373.

Gilson, E. (1939). Dante et la Philosophie. Paris : Vrin.

Lieb, M. (2007). Theological Milton: Deity, Discourse and Heresy in the Miltonic Canon. Pittsburgh: Duquesne University Press.

Jacoff, R. (2008). The Cambridge Companion to Dante. New York: Cambridge University Press.

Mazzotta, G. (1979). Dante, Poet of the Desert: History and Allegory in the Divine Comedy. Princeton: Princeton University Press.

Mee, J. (1992). Dangerous Enthusiasm: William Blake and the Culture of Radicalism in the I790s. Oxford: Clarendon Press.

Mitchell, W.J.T. (1978). Blake's Composite Art: A Study of the Illuminated Poetry. Princeton: Princeton University Press.

Mitchell, W.J.T. (I975). "Blake's Radical Comedy: Dramatic Structure as meaning in Milton", in Blake's Sublime Allegory, ed. Stuart Curran and Joseph Wittreich, Jr. Madison: University of Wisconsin Press, 28I-307.

Pite, R. (1994). The Circle of our Vision: Dante's Presence in English Romantic Poetry. Oxford: Clarendon Press.

Roe, A.J. (1953). Blake's Illustrations to the Divine Comedy. Princeton: Princeton University Press.

Schütze, S., and Terzoli, M.A. (2020). La "Divina Comedia" de Dante. Madrid: Taschen.

Thompson Schnapp, J. (20I4). The Transfiguration of History at the Center of Dante's Paradise. Princeton: Princeton University Press.

Tinkler-Villani, V. (1989). Visions of Dante in English Poetry. Translations of the Commedia from Jonathan Richardson to William Blake. Amsterdam: Rodopi.

Wicksteed, J.W.(1910). Blake's Vision of the Book of Job. Oxford: Clarendon Press.

Wittreich, J. (I97I). William Blake's Illustrations for Milton's "Paradise Regained". London: Rotskopf. 


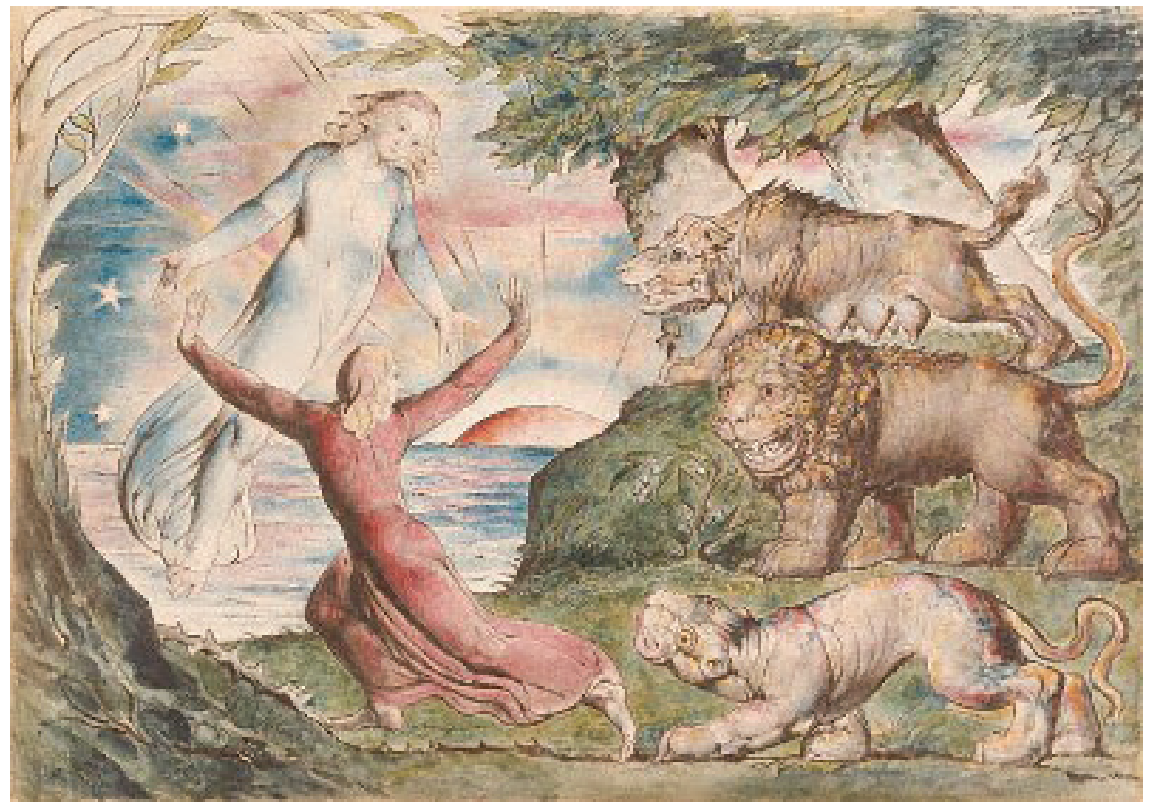

Fig. I. W. Blake, Plate I for Inferno I (Schütze and Terzoli, 2020, p.70-7I) 


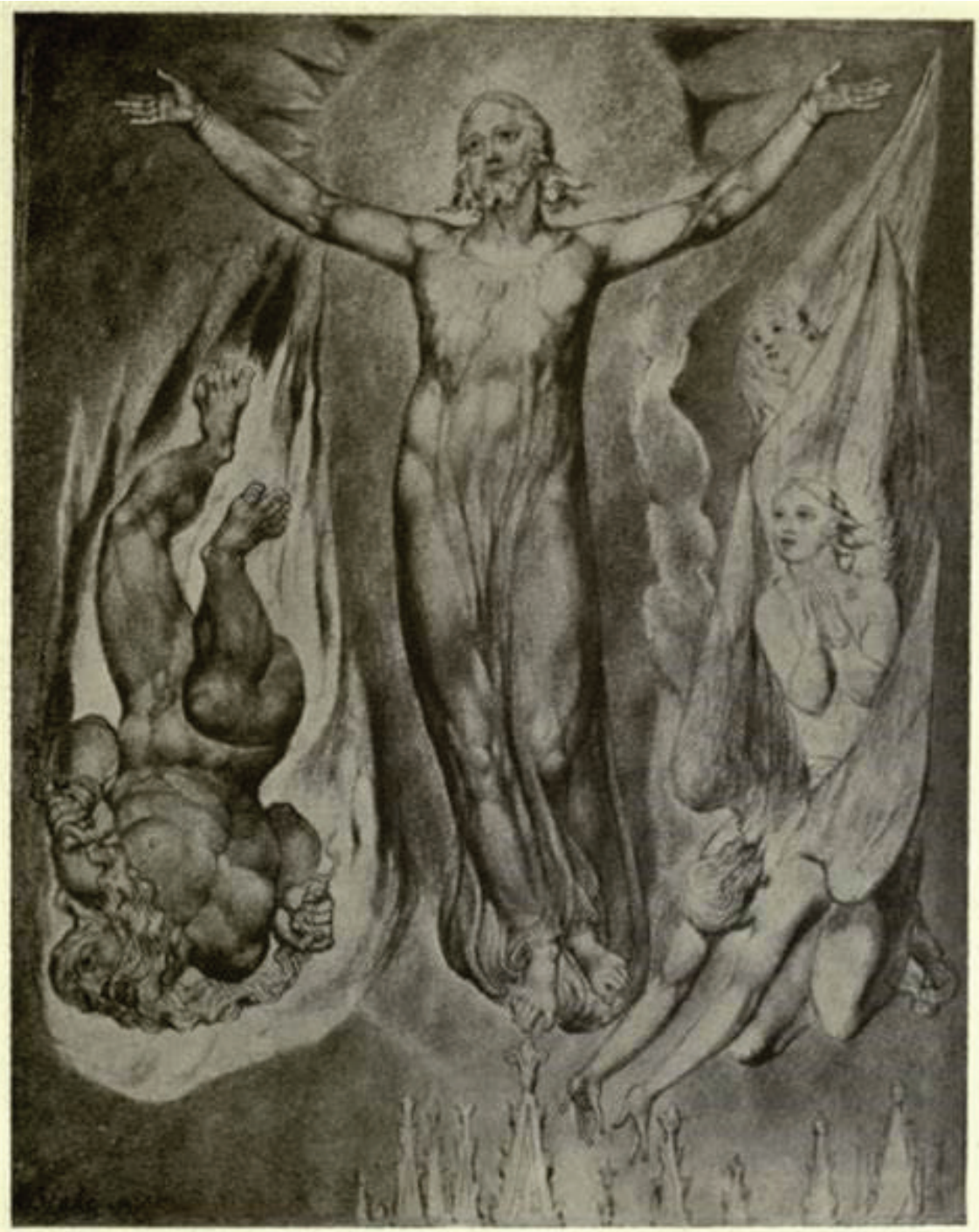

Fig. 2. W. Blake, Plate io for John Milton's Paradise Regained, Book IV (Wittreich, I97I, p. 52) 


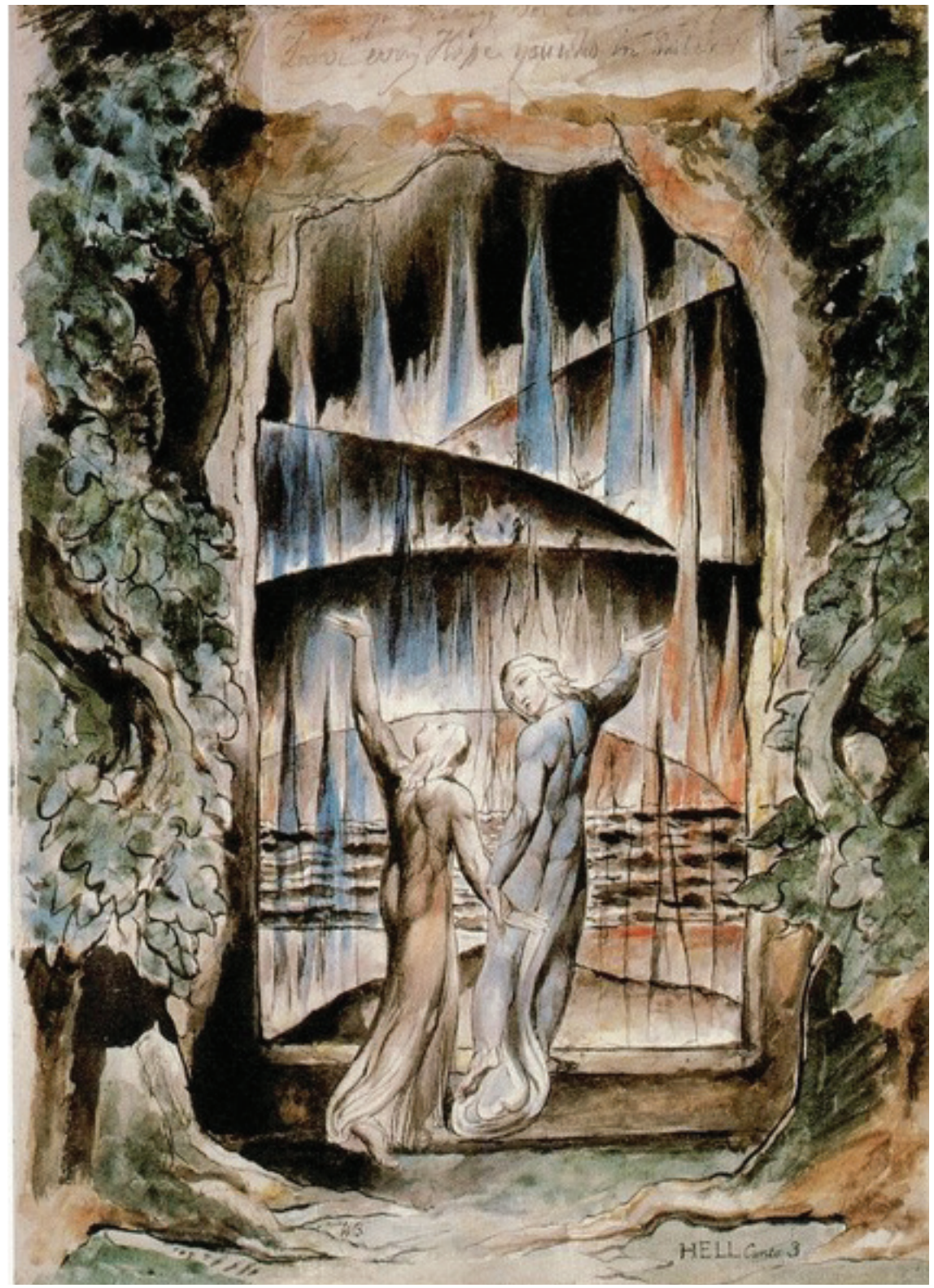

Fig. 3. W. Blake, Plate I for Inferno III (Schütze and Terzoli, 2008, p.80) 


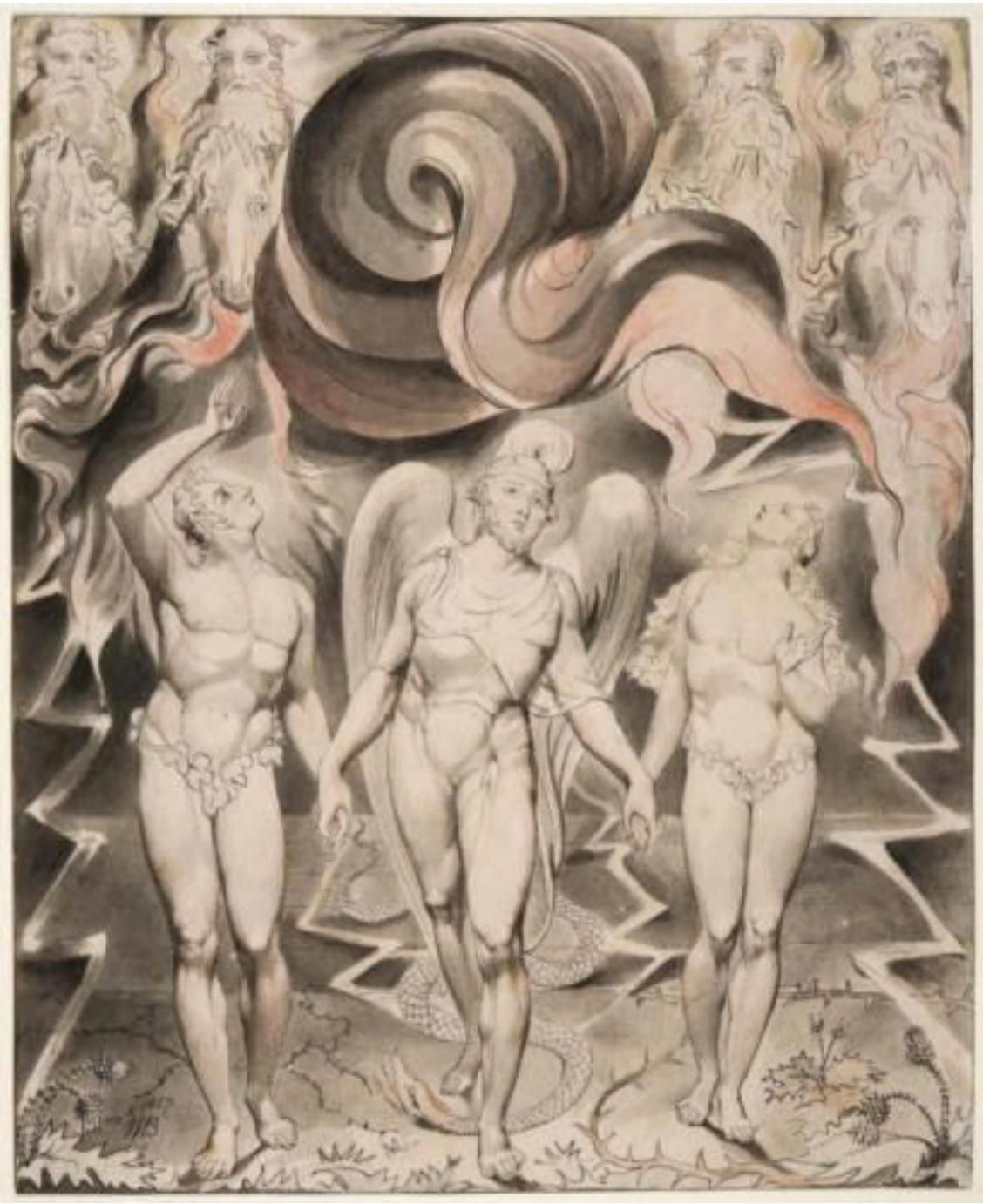

Fig. 4. W. Blake, Final plate for John Milton’s Paradise Lost (Mitchell, I978 , p. 240) 


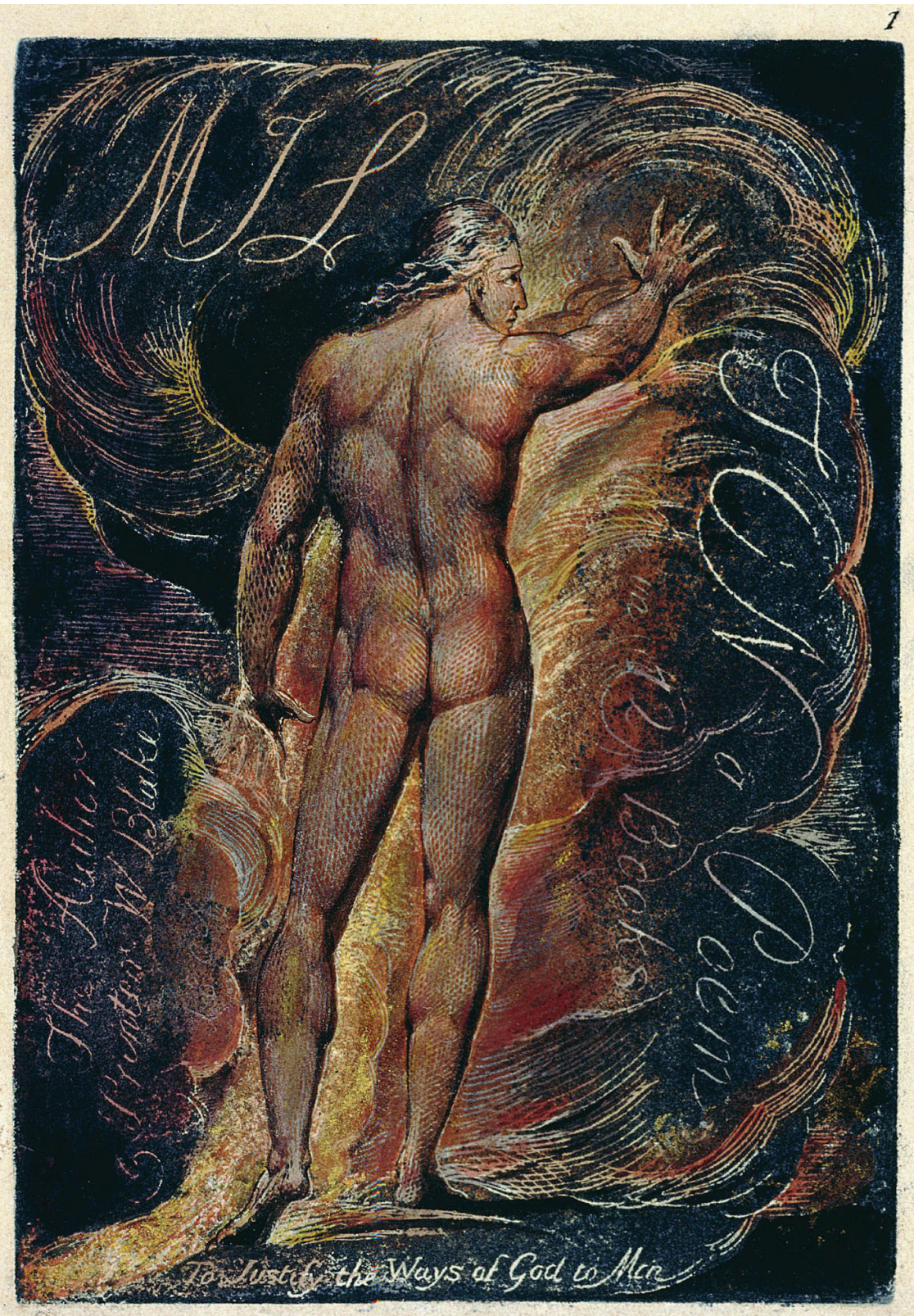

Fig. 5. W. Blake, Frontispiece for Milton, A Poem (Mitchell, 1978, p. 243) 


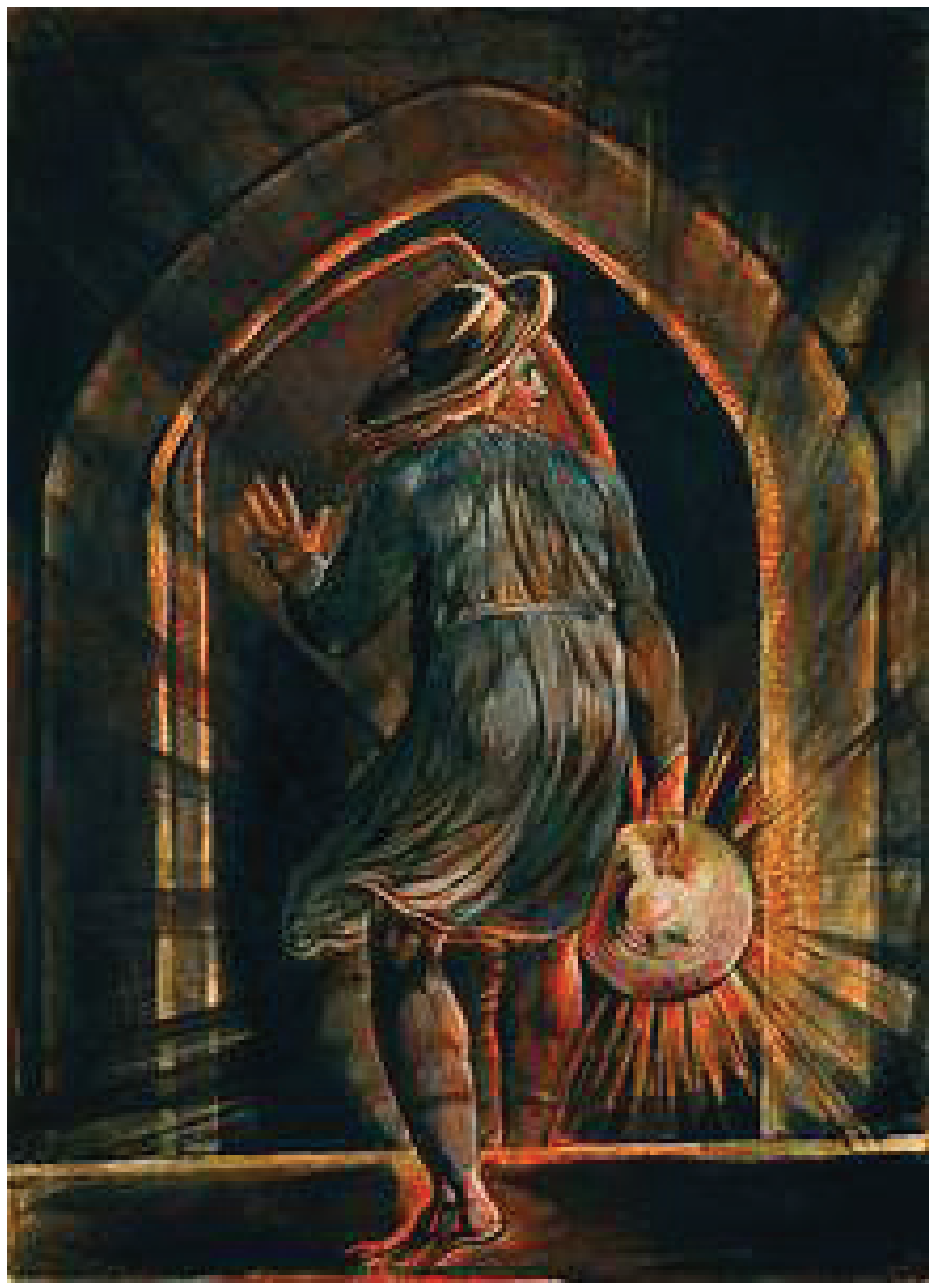

Fig. 6. W. Blake, Frontispiece for Jerusalem (Mitchell, 1978, p. 269) 


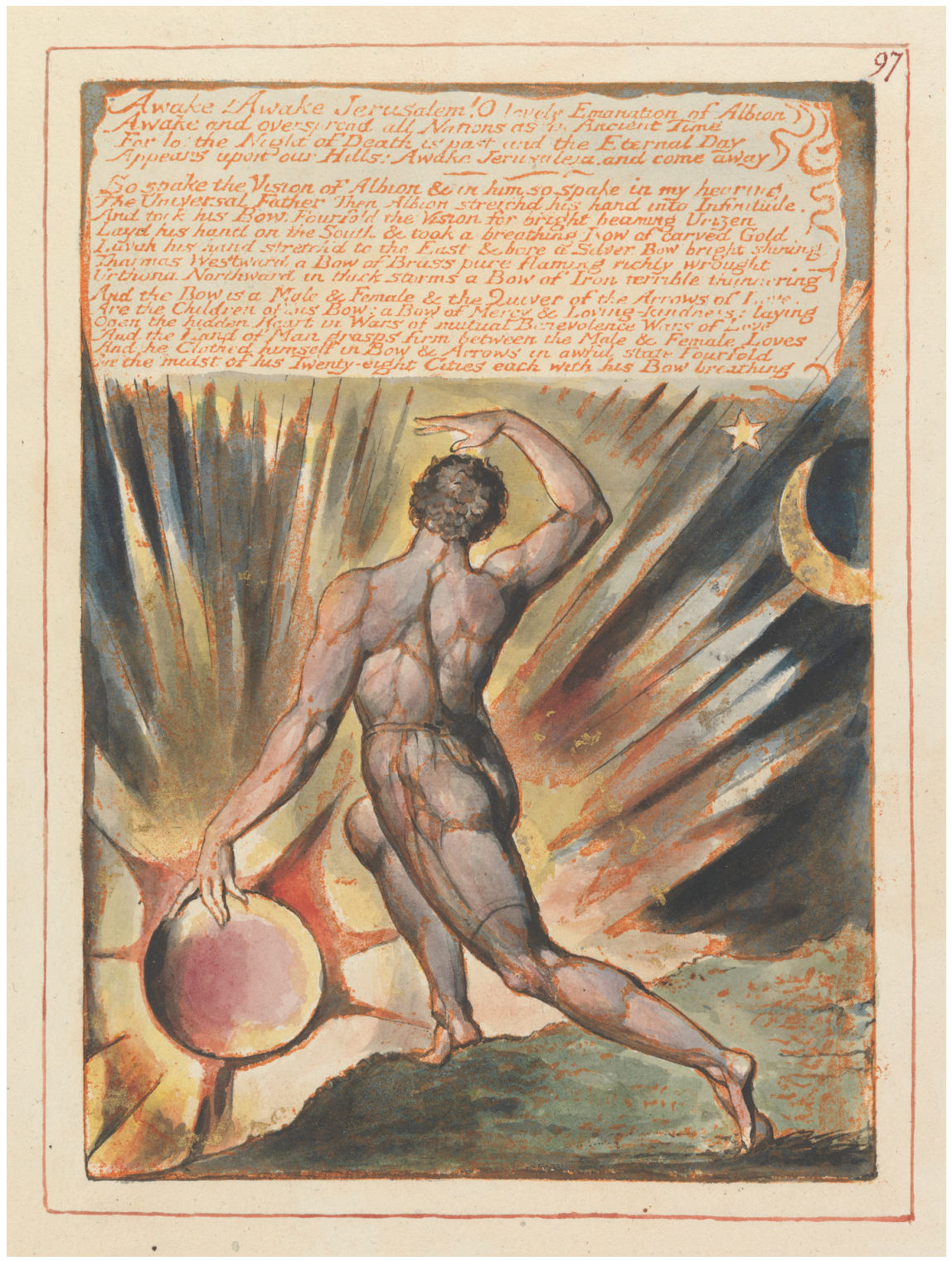

Fig. 7. W. Blake, Plate for Jerusalem (Mitchell, 1978, p. 270). 


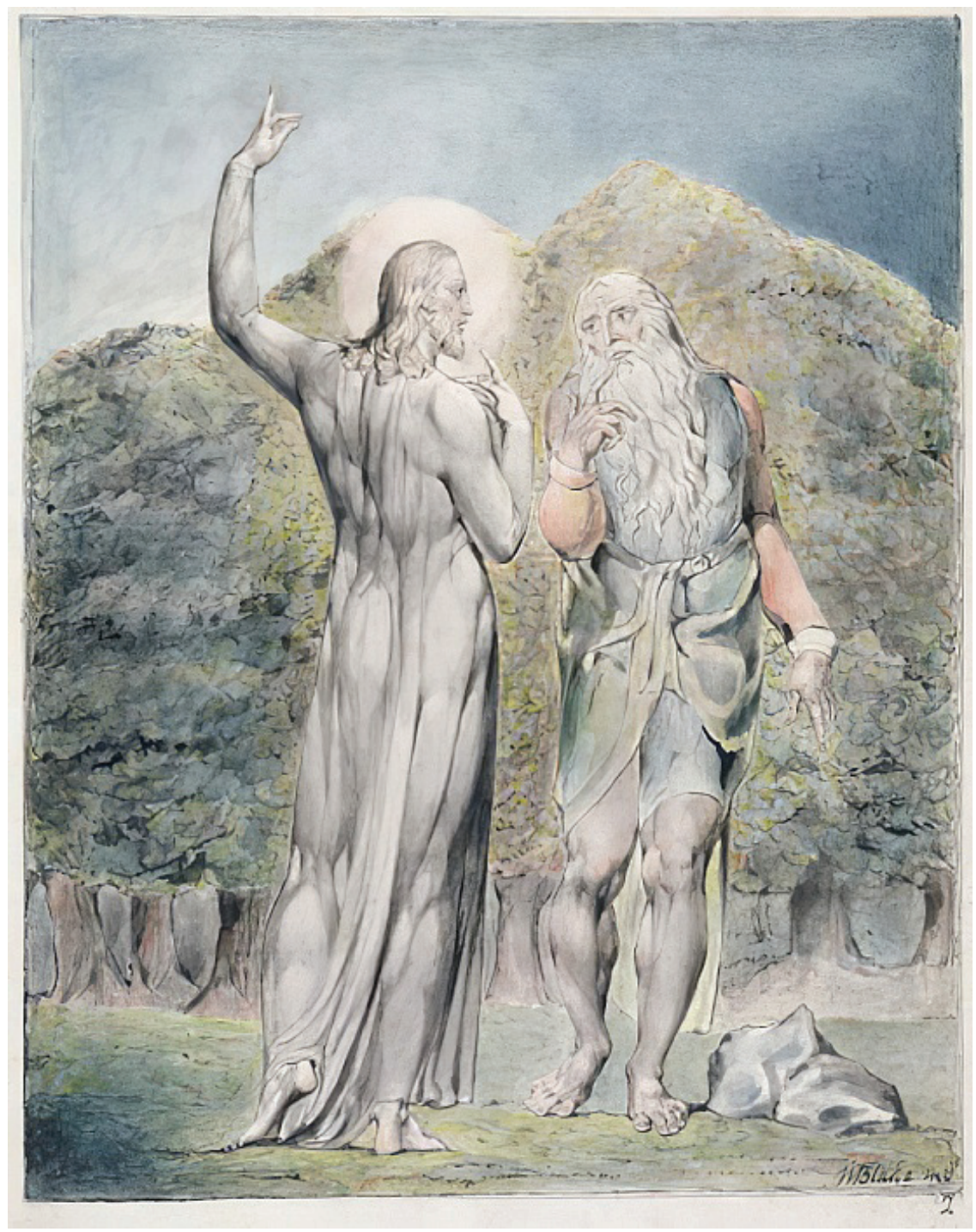

Fig. 8. W. Blake, Plate 2 for John Milton's Paradise Regained (Wittreich, I97I, p. 24). 


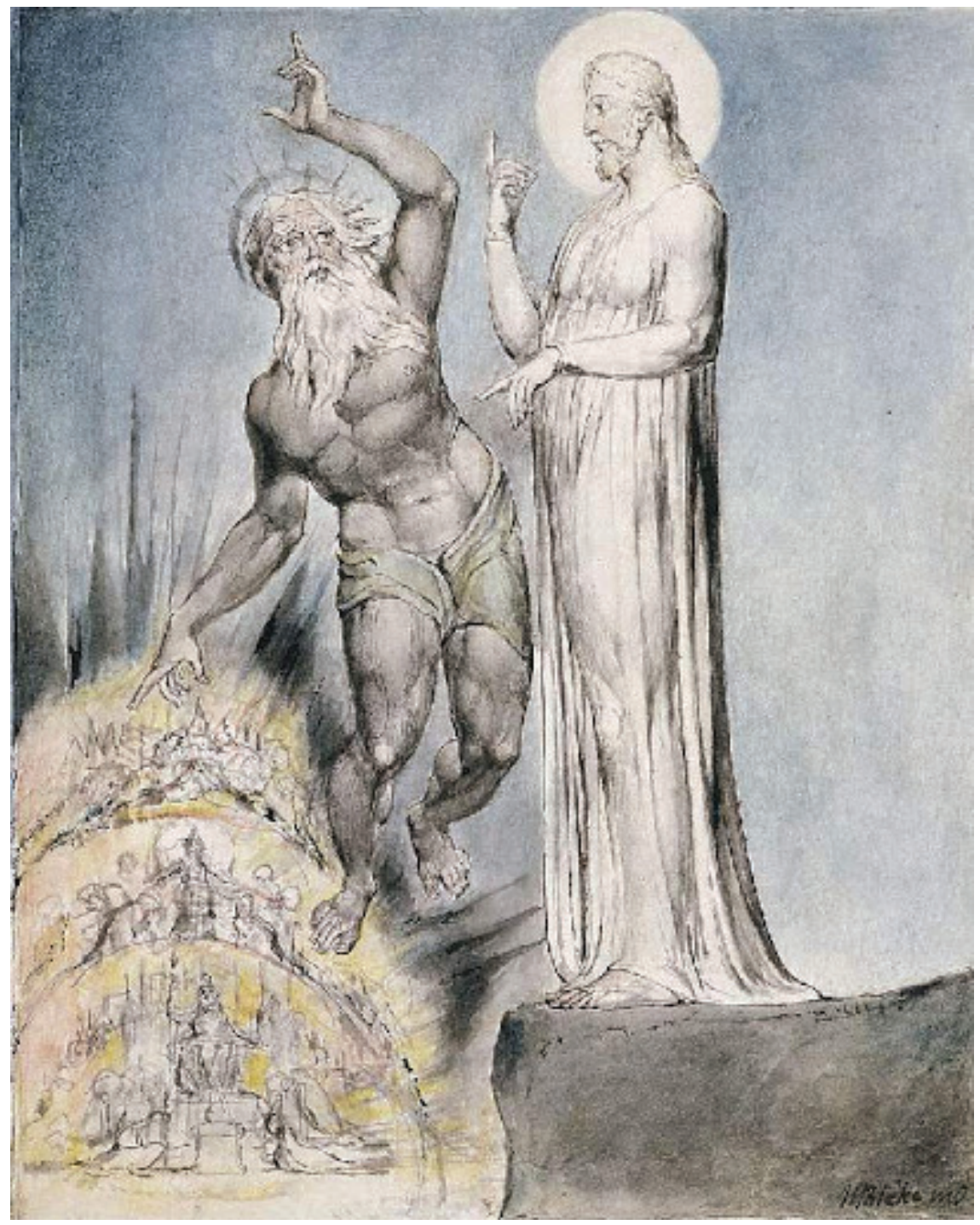

Fig. 9. W. Blake, Plate 7 for John Milton’s Paradise Regained, Book IV (Wittreich, I97I, p. 62). 


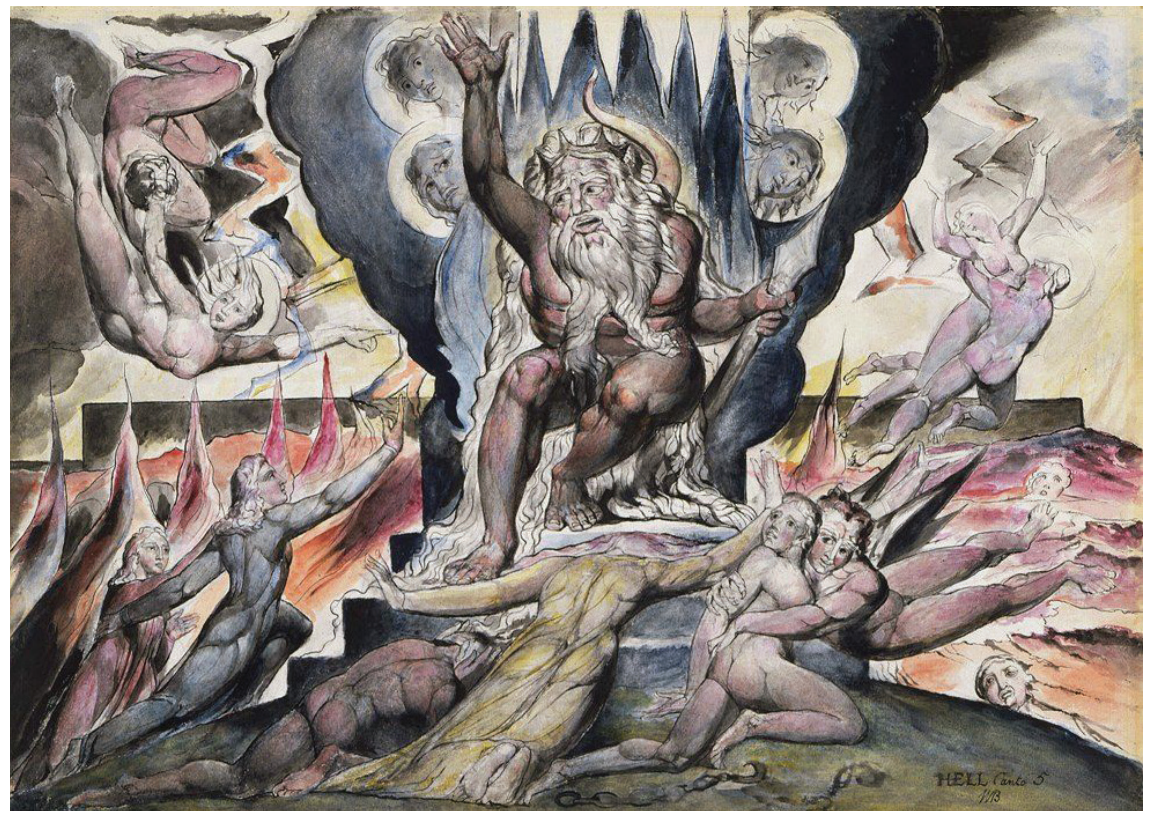

Fig. Io. W. Blake, Plate I for Inferno V (Schütze and Terzoli, 2008, p.IO2-IO3). 
